\title{
European public procurement directives and their implementation in Slovenia
}

UDK: 351.712(497.4)

\author{
Stanka Setnikar Cankar \\ University of Ljubljana, Faculty of Administration \\ stanka.setnikar-cankar@fu-uni-lj.si \\ Veronika Petkovšek \\ University of Ljubljana, Faculty of Administration \\ veronika.petkovsek@fu-uni-lj.si
}

\begin{abstract}
This article presents the results of the research work "Awarding work to external contractors," carried out with a questionnaire in 2009 and 2010 . The research examined the method and scope of public procurement in Slovenian municipalities with more than $\mathbf{8 0 0 0}$ inhabitants. The objectives of the research work were: a comparison of public procurement legislation in selected EU countries; determination of the current situation in the field of public procurement in local government in years 2008 and 2009; determination of similarities and differences in the implementation of contracts; determination of the most common open questions in the implementation of contracts; determination of good practices in public procurement and making the recommendations for changes. Public procurement represents a significant proportion of national budget spending. Municipalities allocate around $20 \%$ of all expenditures to public procurement. The scope and methods of public procurement vary between municipalities. Small-value public procurement is determined by the municipalities in their internal acts, while large-value public procurement has legally prescribed procedures. New legislation on public procurement has brought innovations in the field of public tender and contract award procedures for procurement, which enables greater flexibility in the implementation and realisation of public procurement. This article presents also the European directives on public procurement and an international comparison of public procurement in selected EU and EEA states.
\end{abstract}

Key words: public procurement, municipality, tender and selection procedure, European Directives

JEL: $H 57, H 76$ 


\section{Stanka Setnikar Cankar, Veronika Petkovšek \\ European public procurement directives and their implementation in Slovenia}

\section{Introduction}

Public procurement is an important market sector and a source of income for businesses on the domestic market and the EU single market. Public procurement has therefore become an "essential part of central government business with the private sector" (Šoltes, in Ferfila, 2007, p. 558).

Public procurements are specific procedures leading to the agreement of contracts for the supply of goods, provision of services and construction. Public procurement is intended to stimulate fair competition between tenderers and to allow a contracting authority to purchase goods and services at the lowest possible price for a set level of quality. Public procurements must be carried out primarily by direct and indirect spending units of the national and local government budgets with the objective of meeting its own purchasing requirements in the most economical manner possible (Evenett \& Hoekman, 2005, p.4). Public procurements that include competition ensure effective allocation of resources and introduce the dynamics of competition to a relatively closed system. Sound public procurement procedures lead to more effective and more economic utilisation of public funds, and greater reliability and effectiveness in the public sector (Šoltes, 2008, p. 134).

A public procurement procedure starts with the definition of the contracting authority's purchasing requirements. The contracting authority prepares a tender dossier and defines the subject and scope of the public procurement, the conditions that tenders must meet, and the criteria for selecting the most favourable tenderer. This is followed by the signing of and implementation of the contract (Kranjc, 2004, pp. 53-63).

Public procurement therefore constitutes the supply of the public sector with goods, services and construction and is a broader concept than purchasing, since public procurements include identification of requirements, provision of funds, supply of goods, provision of services, use and implementation oversight (Šoltes, 2008, p. 133).

The size of the public procurement market in Slovenia is illustrated by the results of the surveys from 2005 to 2007, in which 45 Slovenian municipalities with over 8000 inhabitants participated. 
Stanka Setnikar Cankar, Veronika Petkovšek

European public procurement directives and their implementation in Slovenia

Table 1: Value of high-value and low-value public procurements as proportion of $\mathbf{2 0 0 7}$ municipality expenditure

\begin{tabular}{|l|l|c|c|c|c|}
\hline \multirow{2}{*}{$\begin{array}{l}\text { Public procurements as proportion of } \\
2007 \text { municipality expenditure }\end{array}$} & \multicolumn{2}{|c|}{$\begin{array}{c}\text { Municipality type } \\
\text { Total }\end{array}$} & $\begin{array}{c}\text { Total } \\
\text { (\%) }\end{array}$ \\
\cline { 2 - 6 } & $\begin{array}{c}\text { Urban mu- } \\
\text { nicipalities }\end{array}$ & $\begin{array}{c}\text { Other mu- } \\
\text { nicipalities }\end{array}$ & & \\
\hline & Up to 10\% & 2 & 6 & 8 & 21.1 \\
\cline { 2 - 6 } & $20 \%$ to 30\% & 4 & 6 & 10 & 26.3 \\
\cline { 2 - 6 } & $20 \%$ to 30\% & 1 & 10 & 11 & 28.9 \\
\cline { 2 - 6 } & Over 30\% & 2 & 7 & 9 & 23.7 \\
\hline Total & 9 & 29 & 38 & 100.0 \\
\hline
\end{tabular}

Source: Setnikar Cankar, Seljak, Petkovšek, 2009, p.5

The total value of public procurements was compared with 2007 municipality expenditures. The comparison reveals large differences between municipalities, which is probably the consequence of the periodic nature of the investment cycle. In almost half of municipalities, over $20 \%$ of all expenditure was for public procurements, and below 20\% in half of them (Setnikar Cankar, Seljak, Petkovšek, 2009, p. 5).

\section{European public procurement directives}

"The development of public procurement in the European Union has been influenced by the move towards a single market. This is a fundamental part of the European Communities, as illustrated in the international founding treaties. The European Union is the common term for the three international treaties that created the community" (Pivk, 2006, p. 30).

"The member states transferred specifically defined competences by means of these international treaties. In addition to the common agricultural, trade, fishing, transport, health, social and other policies, the main activity and basis for all policy types, is the implementation of the common market through the implementation of four basic freedoms (Treaty establishing the European 
Stanka Setnikar Cankar, Veronika Petkovšek

European public procurement directives and their implementation in Slovenia

Community or Treaty of Rome (TEC), 1957): free movement of goods, services, capital and labour. This objective can only be achieved, if individuals and business can compete equally for business offered by public and private organisations spending public funds. Free trade between member states and the fundamental rules of public procurement was already indirectly in the Treaty establishing the European Community (TEC). Specific rules in the Treaty of Rome prohibit some of the most frequent forms of discrimination, but do not lay down any provision on the transparency of operations and competition in acquiring business. The European Union therefore harmonised the area of public procurement via secondary legislation. This area of law is laid down by regulations, directives and guidelines of the European Union" (Pivk, 2006, p.30).

"The guidelines or directives that regulate public procurement are general and abstract acts of European Union bodies that apply to the member states. They are generally implemented directly. Member states must harmonise their own legislation within a set time after the guidelines are adopted. The guidelines are implemented after being transposed into member state legislation and define a common denominator, to which the member state must adapt" (Govekar, 2008, p.7).

"Member states, and hence also the European Union, regulate the area of public procurement in order to meet objectives such as: effective public spending, ensuring full and open competition, public trust, rationalising operations, preventing corruption, ensuring equality and non-discrimination. Primarily from the European Union's point-of-view, public procurements represent large-scale finances and an instrument to ensure the four freedoms on which the common market is based" (Mužina \& Vesel, 2007, p. 16). Nemec (2010) writes that although Central and Eastern European states have public procurement offices, after verifying their websites he found that after 15 years of public procurement legislation being in place, the results were still very poor. The provision of online consultancy on contract agreement with external contractors was at a very low level.

"European law regulates the institute of public procurements in three sets of directives:

First, procedures for the award of public contracts:

Directive 2004/18/EC on the coordination of procedures for the award of public works contracts, public supply contracts and public service contracts 
Stanka Setnikar Cankar, Veronika Petkovšek

European public procurement directives and their implementation in Slovenia

(OJ EU, no L 134/2004 of 31 April 2004), which replaced the frequently amended Directives 92/50/EEC, 93/36/EEC and 93/37/EEC.

Second, procurement procedures in the water, energy, transport and postal services sectors:

Directive 2004/17/EC on coordinating the procurement procedures of entities operating in the water, energy, transport and postal services sectors (OJ EU, no L 134/2004, of 31 April 2004), which replaced the frequently amended Directive 93/38/EEC.

Third, legal remedies:

Council Directive 89/665/EEC (OJ EU, 1989, L 395), on the coordination of the laws, regulations and administrative provisions relating to the application of review procedures to the award of public supply and public works contracts and Council Directive 92/13/EEC (OJ EU, 1992, L 076), which lay down the rules on legal remedies in procurement procedures in the water, energy, transport and telecommunications sectors." (Mužina \& Vesel, 2007, pp. 16-17)

\section{Comparison of public procurements in selected EU member states}

\subsection{Austria}

Austria's Federal Law on Public Procurement distinguishes between the following forms of procedure for public tenders and public contract awards: public procedure, non-public procedure (i.e. restricted) with prior publication, non-public procedure without prior publication, negotiated procedure with prior publication, negotiated procedure without prior publication, and direct award of contract without prior publication. The following procedures may also be used: dynamic procurement system, framework agreement, competitive dialogue and electronic auction.

The contracting authority may freely select between public or non-public procedures with disclosure. Regulations defined in the Federal Law on Public Procurement must be met before any other form of procedure is selected. The non-public procedure without prior publication, the negotiated procedure without prior publication, and direct award of contract are only permitted if the 
Stanka Setnikar Cankar, Veronika Petkovšek

\section{European public procurement directives and their} implementation in Slovenia

value of the public contract is at or below the threshold value (Federal Public Procurement Office, 2010).

\subsection{Hungary}

Hungary has the Public Procurement Act, which regulates public procurements in accordance with Directive 2004/18/EC and public works contracts in accordance with Directive 2004/17/EC.

The Hungarian Public Procurement Act distinguishes between singlephase and two-phase procedures for public tenders and public contract awards: the participation stage and the tendering stage. Within this act, contracting authorities are free to select an open procedure or the "invitation" procedure (restricted procedure in accordance with Directive 2004/18/EC), in which only qualified participants may submit tenders in the participation state. All other procedures are subject to specific regulations. A contracting authority may only use a negotiated procedure, if an open or restricted procedure or competitive dialogue has failed, in exceptional cases in contracts for public works and goods or services. The contracting authority may only use a competitive dialogue if it is not able to define the technical specifications or the type of procurement or the legal and/or financial make-up of the procurement within the normal timeframe for a public procurement procedure. In addition to these procedures, contracting authorities may also use a framework agreement or dynamic purchasing system (The International Comparative Legal Guide to: Public Procurement 2010, 2010, pp. 117-121).

\subsection{Germany}

Germany fully transposed the European directives (Directive 2004/17/EC and Directive 2004/18/EC) in its Restraint of Competition Act, Ordnance on the Award of Public Contracts and the Ordnance on Public Works Procurement.

In accordance with the EU directives, the German public procurement act defines four procedures for public tenders and the award of public contracts that exceed the threshold value. These procedures are: public tendering (open procedure), restricted tendering (restricted procedure), private tender (negotiated procedure) and competitive dialogue. A contracting authority that is subject to the federal Ordinance on Public Works Procurement may choose between the procedures stated, if there has been a prior publication of a pan- 
Stanka Setnikar Cankar, Veronika Petkovšek

European public procurement directives and their implementation in Slovenia

European invitation tender. All other contracting authorities must in general use an open procedure, though restricted procedures, negotiated procedures or competitive dialogues are also possible under the conditions defined in EU directives. An open procedure, restricted procedure or negotiated procedure can be used for public procurements under the threshold value (The International Comparative Legal Guide to: Public Procurement 2010, 2010, pp. 105110).

\subsection{Norway}

Norwegian legislation on public procurements includes the Public Procurement Act, which implements Directive EU 2004/18/EC, the Regulation on Public Procurements, which also implements Directive 2004/18/EC, and the Regulation on Public Works Procurement, which implements Directive 2004/17/EC. Norwegian legislation covers all forms of public procurement from the group of EU public procurement directives, i.e. public procurement of goods, services and public works (Norway, 2010).

Norway's legal arrangement for public procurement prescribes four different procedures for public tenders and awarding public contracts: 1. open procedure, enabling the participation of all interested tenderers, but prohibiting negotiations between the public contracting authority and potential tenderers. The procedure is used for all forms of public procurement; 2. restricted procedure, which only permits invited tenderers to participate, with negotiations prohibited; the procedure is used for all forms of public procurement; 3. competitive dialogue, which includes dialogue between public contracting authorities and potential tenderers on specifications before tenderers submit their tender; and 4. negotiated procedure, where the contracting authority negotiates with one or more potential tenderer. The use of the third and fourth procedure is limited (The International Comparative Legal Guide to: Public Procurement 2010, 2010, pp. 181-185).

\subsection{Sweden}

Sweden has a Public Procurement Act that applies to the private sector, and the Public Works Procurement Act, which applies to public works in the fields of water, transport, energy and postal services. These two acts include 
Stanka Setnikar Cankar, Veronika Petkovšek

European public procurement directives and their implementation in Slovenia

all public procurements for goods, services and construction, and implement European Directives 2004/18/EC and 2004/17/EC (Public Procurement, 2010).

In Sweden an open procedure, restricted procedure or negotiated procedure may be used for public procurements over a prescribed threshold value. The rules for implementing these processes are harmonised with the EU directives. Despite this, the Public Procurement Act permits free selection between open and restricted procedures, while the Public Works Procurement Act permits free selection between all three procedural forms. A simplified, selective or direct procedure may be used for public procurements below the prescribed threshold. In a simplified procedure all suppliers are entitled to submit tenders, with participating suppliers bound to submit a tender, while the contracting authority may negotiate with one or more of them. In a selective procedure all suppliers are permitted to submit a tender, with the contracting authority inviting some tenderers to submit tenders, and able to negotiate with one or more of them. The contracting authority is free to choose between the two procedures. A direct procedure does not require tenderers and may only be used for low-value public procurements or on special grounds (The International Comparative Legal Guide to: Public Procurement 2010, 2010, pp. 244-247).

\subsection{Similarities and differences between public pro- curement in selected states}

A comparison of selected EU member states (or EEA member in the case of Norway) indicates that the selected states implement Directives 2004/18/EC and 2004/17/EC in their public procurement legislation. The public procurement legislation of the selected states includes prescribed procedures for public tenders and public contract awards that must be respected in relation to prescribed threshold values for contracts. In Austria contracting authorities may freely select between public or non-public procedures with disclosure (i.e. restricted procedures with prior publication). In Hungary, Norway and Sweden, contracting authorities may freely select between open and restricted procedures. There are legal regulations in the individual member states that apply to the use of other procedures, such as negotiated procedures, competitive dialogue, framework agreements and dynamic purchasing systems.

The type and use of public procurement procedures is very similar among the different states, since they all have transposed the European directives into their own legislation. Each state also has its own specific national features. In Hungary distinction is made between single-stage and dual-stage 
Stanka Setnikar Cankar, Veronika Petkovšek

European public procurement directives and their implementation in Slovenia

public tender and contract award procedures. In Germany the contracting authority may freely choose between prescribed procedures, if a pan-European tender has already been published. If not, it must use an open procedure.

\section{Amendments to legislation}

The adoption by the European Parliament and Council of two new European directives (Directives 2004/18/EC and 2004/17/EC) at the end of 2006 led to the amendment of the Slovenian legislation. It has been in force since early 2007. The amended Public Procurement Act (PPA-2) introduced a number of innovations to public procurement practice. It introduced new procurement procedures: the dynamic purchasing system, electronic auction, and competitive dialogue. The Act on Public Procurement in Water Management, Energy, Transport and Postal Services (APPwetp) was adopted in parallel (Mužina \& Vesel, 2007, p. 18).

In June 2007 the Ministry of Finance's public procurement portal was started where contracting authorities can directly send publication of contract notice and tender dossiers, in accordance with the PPA-2 and APPwetp. The creation of the portal was a legal obligation, and its purpose and advantages was above all to reduce administrative obstacles and to modernise the method of handling public procurement, with publication and access to information on public procurements available in a one-stop-shop, reducing costs for contracting authorities and allowing deadlines for submission of tenders to be shortened (Public Procurement Portal, OGRS, 2010).

The PPA-2 offered greater flexibility in public procurement implementation. Nevertheless, the need has arisen to amend a number of individual solutions set out in the act, mainly in terms of increasing the importance of "market price" in public procurement procedures. The Act amending the Public Procurement Act (PPA-2A, Act amending the Public Procurement Act, OGRS, no 16/08) therefore changed the definition of the term "unacceptable tender", which now also includes tenders with a price higher than the market price for the subject of public procurement. The amended act also permits or commits the contracting authority to using an electronic auction if tenders are unacceptable. If an electronic auction fails to achieve a reduction in price, the contracting authority ends the process as unsuccessful; it may then hold negotiations (PPA2A). 


\section{Stanka Setnikar Cankar, Veronika Petkovšek \\ European public procurement directives and their implementation in Slovenia}

The PPA-2A has also led to changes in reporting statistical data to the Ministry of Finance. A system for automatic reporting of statistical data on public procurement was also established at the start of 2009. For high-value public procurements it was only necessary to submit 2008 data to the Ministry of Finance while it was no longer necessary to submit data for high-value public procurements in 2009 as they are captured automatically from the public procurement portal. Municipalities were exempt from the obligation to report statistical data on low-value procurements in 2008 and that also applied in 2009.

\section{Presentation of the survey}

The type and scope of public procurements in Slovenian municipalities and their tender and award procedures were studied in the research work "Awarding Work to External Contractors." The research included municipalities, which had over 8000 inhabitants on 30 June 2007. Of the 65 municipalities meeting the criteria, 45 agreed to participate. The survey was carried out from 10 January 2009 to 28 February 2009 with assistance from postgraduate students on the Administration master's programme. The survey was repeated in 2010, from 4 June 2010 to 25 June 2010, again with assistance from graduate students. The research included municipalities of varied size, but all with over 8000 inhabitants. Of the 48 municipalities contacted (including 9 urban municipalities), only 25 responded to the survey, 4 of them being urban municipalities. Some participating municipalities completed the survey in full, others only in part.

\section{Results}

\subsection{Type of procurement services}

The objective of public procurement is to acquire the most favourable tender possible on the basis of a pre-defined procedure and a number of competitive tenders. Contracting authorities are required to purchase goods, order services and construction in accordance with rules defined by the relevant act and the regulations issued on its basis. 
Stanka Setnikar Cankar, Veronika Petkovšek

European public procurement directives and their implementation in Slovenia

Table 2: Types of service municipalities awarded to external contractors in public procurement procedures in 2008 and 2009

\begin{tabular}{|l|c|c|c|c|c|c|c|c|}
\hline \multirow{2}{*}{ Service type } & \multicolumn{5}{|c|}{ No of urban municipalities } & \multicolumn{3}{c|}{$\begin{array}{c}\text { No of municipalities with } 10000 \text { to } 50000 \\
\text { inhabitants }\end{array}$} \\
\cline { 2 - 10 } & always & frequently & occasionally & never & always & frequently & occasionally & never \\
\hline Legal services & 0 & 0 & 3 & 1 & 1 & 1 & 10 & 0 \\
\hline $\begin{array}{l}\text { Information } \\
\text { services }\end{array}$ & 0 & 2 & 2 & 0 & 0 & 6 & 5 & 1 \\
\hline Security services & 1 & 1 & 1 & 1 & 2 & 5 & 2 & 3 \\
\hline $\begin{array}{l}\text { Cleaning services } \\
\text { Vehicle fleet }\end{array}$ & 2 & 1 & 1 & 0 & 4 & 4 & 2 & 2 \\
\hline $\begin{array}{l}\text { maintenance } \\
\text { services }\end{array}$ & 1 & 1 & 2 & 0 & 3 & 7 & 2 & 0 \\
\hline
\end{tabular}

Source: Faculty of Administration survey 2009, 2010

The services most frequently awarded to external contractors in the surveyed municipalities (4 urban and 12 municipalities with 10000 to 50000 inhabitants) in 2008 and 2009 were cleaning services and vehicle fleet maintenance services, followed by security and information services and, less frequently, legal services.

Public procurement can be divided into low-value public procurements, and high-value public procurements.

\subsection{Low-value public procurements}

In Slovenia each contracting authority must organise the field of low-value public procurements in an internal act, so the procedures they use differ (Bohnec et al., 2005, p. 142). The new amended Public Procurement Act does

\footnotetext{
${ }^{1}$ Urban municipalities: Ljubljana, Kranj, Velenje and Slovenj Gradec.

${ }^{2}$ Municipalities with 10000 to 50000 inhabitants: Lendava, Laško, Jesenice, Rogaška Slatina, Sežana, Sevnica, Izola, Vrhnika, Grosuplje, Ljutomer, Zagorje ob Savi and Ormož.
} 
Stanka Setnikar Cankar, Veronika Petkovšek

\section{European public procurement directives and their} implementation in Slovenia

not define the term "low-value public procurement", but the public procurement procedure is not prescribed for goods and services purchases under 10000 euros and construction under 20000 euros in order to achieve greater flexibility to purchasing goods and services. For purchases of goods and services worth between 20000 and 40000 euros and construction worth between 40000 and 80000 euros, the contracting authority can implement a low-value public procurement procedure or any other procedure (Act amending the Public Procurement Act (PPA-2B), Official Gazette of the Republic of Slovenia, no 19/2010).

Table 3: Most common forms of public procurement used by municipalities

\begin{tabular}{|l|c|c|c|c|}
\hline \multirow{2}{*}{ Public procurement awarded } & \multicolumn{2}{|c|}{$\begin{array}{c}\text { Proportion of public } \\
\text { contracts awarded by } \\
\text { purchase order (\%) }\end{array}$} & \multicolumn{2}{|c|}{$\begin{array}{c}\text { Proportion of public contracts } \\
\text { awarded by contract (\%) }\end{array}$} \\
\cline { 2 - 5 } & 2008 & $2009^{3}$ & 2008 & $2009^{4}$ \\
\hline Goods & 30.7 & 39.0 & 10.3 & 18.3 \\
Services & 63.3 & 56.5 & 69.0 & 67.3 \\
Construction & 6.0 & 4.5 & 20.7 & 14.4 \\
\hline Total & 100.0 & 100.0 & 100.0 & 100.0 \\
\hline
\end{tabular}

Source: Faculty of Administration survey 2009, 2010

In 2008 the average number per municipality of low-value public procurements awarded was 531 by purchase order and 76 by contract. The majority of low-value public contracts were in the service field, which constituted $63.3 \%$ of procurements by purchasing order and $69.0 \%$ by contract. In the other two categories the differences were clearer, with procurements awarded for goods

3 Municipalities with 10000 to 50000 inhabitants: Lendava, Laško and Rogaška Slatina.

4 Municipalities with 10000 to 50000 inhabitants: Lendava, Laško and Rogaška Slatina. 
Stanka Setnikar Cankar, Veronika Petkovšek

European public procurement directives and their implementation in Slovenia

constituting $30.7 \%$ of public procurements by purchasing order, and only $10.3 \%$ by contract, while awards for construction constituted $6.0 \%$ of procurements by purchase order and $20.7 \%$ by contract.

In 2009 the average number of low-value public contracts awarded was 516 by purchase order and 32 by contract in the 3 surveyed municipalities with 10000 to 50000 inhabitants. Public procurements awarded by purchase order predominated. The majority of low-value public contracts were in the service field, which constituted $56.5 \%$ of procurements by purchasing order and $67.3 \%$ of procurements by contract. The proportion of procurements awarded for goods and construction were lower, with $39 \%$ of procurements by purchase order and $18.3 \%$ of procurements by contract being for goods, while $4.5 \%$ of procurements by purchase order, and $14.4 \%$ of procurements by contract were for construction.

During the years 2008 and 2009 the percentage of public contracts awarded by purchase order and by contract has increased for goods and decreased for services and construction.

\subsection{High-value public procurements}

High-value public procurements are procurements worth 40000 euros or over for goods and services and 80000 euros or over for construction, and are characterised by the fact the contracting authority must select from a number of set procedures: 1. open procedure; 2. procedure with prequalification of tenderers; 3. competitive dialogue; 4. negotiated procedure without prior publication, and 5. negotiated procedure after prior publication (PPA-2B). Contracting authorities may only freely choose between an open procedure and a procedure with prequalification of tenderers, with other procedures only implemented if specific criteria defined by the act are met.

An open procedure is the most frequently used public procurement procedure. All parties interested in acquiring the public procurement may submit tenders prepared in accordance with the contracting authority's requirements defined in the tender dossier (Art. 25, Public Procurement Act (PPA-2), OGRS, no 128/06). A procedure with prequalification of tenderers does not differ in essence from an open procedure. A contracting authority uses this procedure if the subject of public procurement is an ongoing contractual need, which the contracting authority cannot define in advance in terms of scope and time (Mužina \& Vesel, 2007). 
Stanka Setnikar Cankar, Veronika Petkovšek

\section{European public procurement directives and their} implementation in Slovenia

A negotiated procedure can only take place in two forms, either after prior publication or without prior publication. The procedure enables tenderers to harmonise their contractual conditions with those of the contracting authority. A negotiated procedure after prior publication is possible, if the contracting authority has attempted an open procedure and a procedure with prior qualification of tenderers and failed, or if it fails to acquire regular or acceptable tenders in a competitive dialogue. A procedure without prior publication can be used if, for various reasons, conditions are only met by one tenderer (Arts. 28 and 29, PPA-2).

Competitive dialogue is a major new feature of the amended Public Procurement Act (PPA-2). It is intended for very complex procurements and is used when the use of an open procedure or procedure with prequalification of tenderers is not possible due to the complexity of the public procurement (Art. 27, PPA-2). The purpose of competitive dialogue is to enable the contracting authority's requirements to be adapted to market conditions and to enable the contracting authority to set its final conditions only after possibilities have been weighed within a competitive dialogue.

A framework agreement is another new feature of the PPA-2 and is agreed on the basis of a prior open procedure, procedure with prequalification of tenderers, negotiated procedure after prior publication or negotiated procedure without prior publication. A distinction can be made between agreements with one tenderer or agreements with at least three tenderers (Art. 32, PPA-2). The next new feature of the PPA-2 is the dynamic purchasing system, which is used for standardised purchases. The system enables easier simultaneous communication via electronic means, if a larger number of tenderers are involved. This is a development on the open procedure and procedure with prior qualification of tenderers.

An electronic auction offers the contracting authority the possibility of awarding a public contract by electronic auction within an open procedure, procedure with prequalification of tenderers, or a negotiated procedure after prior publication, if the technical specification of the procurement can be defined accurately and unambiguously (Art. 35, PPA-2). The electronic auction enables prices to be ranked using automatic evaluation methods. A public auction enables costs to be lowered and reduces the level of administration by public bodies (Matas, 2006). 
Stanka Setnikar Cankar, Veronika Petkovšek

European public procurement directives and their implementation in Slovenia

Table 4: The most commonly used tender procedures for high-value public procurements by municipalities in 2008

\begin{tabular}{|c|c|c|c|c|c|c|c|c|c|}
\hline \multirow{3}{*}{ Procedure type } & \multirow{3}{*}{$\begin{array}{l}\text { No of } \\
\text { responses }\end{array}$} & \multicolumn{8}{|c|}{ Responses (\%) } \\
\hline & & \multicolumn{4}{|c|}{ Goods and services } & \multicolumn{4}{|c|}{ Construction } \\
\hline & & always & $\begin{array}{l}\text { frequ- } \\
\text { ently }\end{array}$ & $\begin{array}{l}\text { occasio- } \\
\text { nally }\end{array}$ & never & always & $\begin{array}{l}\text { frequ- } \\
\text { ently }\end{array}$ & $\begin{array}{l}\text { occasio- } \\
\text { nally }\end{array}$ & never \\
\hline $\begin{array}{l}\text { Call for tenders after } \\
\text { prior publication }\end{array}$ & 36 & 13.2 & 26.3 & 26.3 & 34.2 & 2.8 & 19.4 & 44.4 & 33.3 \\
\hline $\begin{array}{l}\text { Negotiated procedure } \\
\text { after prior publication }\end{array}$ & 34 & 0.0 & 11.8 & 38.2 & 50.0 & 0.0 & 2.9 & 47.1 & 50.0 \\
\hline Open procedure & 38 & 36.8 & 36.8 & 10.5 & 15.8 & 50.0 & 31.6 & 13.2 & 5.3 \\
\hline Other procedures & 27 & 0.0 & 3.7 & 11.1 & 85.2 & 0.0 & 3.7 & 14.8 & 81.5 \\
\hline
\end{tabular}

Source: Faculty of Administration survey 2009

The most common procedures for goods and services and construction in the surveyed municipalities in 2008 were open procedures. In some municipalities, calls for tenders after prior publication were always or frequently used, with other procedures used rarely. The only other procedures mentioned were negotiated procedures without prior publication and prequalification procedures.

Table 5: The most commonly used tender procedures for high-value public procurements by municipalities in 2009

\begin{tabular}{|c|c|c|c|c|c|c|c|c|c|}
\hline \multirow{3}{*}{ Procedure type } & \multirow{3}{*}{$\begin{array}{c}\text { No of } \\
\text { responses }\end{array}$} & \multicolumn{8}{|c|}{ Responses (\%) } \\
\hline & & \multicolumn{4}{|c|}{ Goods and services } & \multicolumn{4}{|c|}{ Construction } \\
\hline & & always & $\begin{array}{l}\text { frequ- } \\
\text { ently }\end{array}$ & $\begin{array}{l}\text { occasio- } \\
\text { nally }\end{array}$ & never & always & $\begin{array}{l}\text { frequ- } \\
\text { ently }\end{array}$ & $\begin{array}{l}\text { occasio- } \\
\text { nally }\end{array}$ & never \\
\hline $\begin{array}{l}\text { Call for tenders after } \\
\text { prior publication }\end{array}$ & 11 & 0.0 & 63.6 & 9.1 & 27.3 & 0.0 & 54.5 & 27.3 & 18.2 \\
\hline $\begin{array}{l}\text { Negotiated procedure } \\
\text { after prior publication }\end{array}$ & 10 & 0.0 & 0.0 & 50.0 & 50.0 & 0.0 & 10.0 & 30.0 & 60.0 \\
\hline Open procedure & 10 & 30.0 & 50.0 & 20.0 & 0.0 & 30.0 & 60.0 & 10.0 & 0.0 \\
\hline Other procedures & 9 & 0.0 & 0.0 & 11.1 & 88.9 & 0.0 & 0.0 & 11.1 & 88.9 \\
\hline
\end{tabular}

Source: Faculty of Administration survey 2010 


\section{Stanka Setnikar Cankar, Veronika Petkovšek \\ European public procurement directives and their implementation in Slovenia}

In 2009 the most frequently used procedures for goods and services and construction by surveyed municipalities (11 municipalities with 10000 to 50000 inhabitants) were open procedures, while they frequently or occasionally used procedures after prior publication and other procedures, but rarely or never used negotiated procedures after prior publication.

Kovač (2010) offers recommendations regarding the selection of procedures in the event of simple and complex public procurement projects. In line with the principle of ensuring competition between tenderers, for simple projects he recommends the use of a basic public tender, the award of contract by open procedure or award of contract by a procedure with prequalification of tenderers. For complex projects he proposes negotiations - either a competitive dialogue, award of contract by negotiated procedure, or any of the established variations of those forms.

\section{Oversight of public procurements}

Procedures to award public procurements are subject to external oversight by the National Review Commission and the Court of Audit. The Court of Audit carries out scrutiny at various levels of the public procurement process, from identifying the need for public procurement, implementing the public procurement award procedure, and selecting the most favourable tenderer, to conclusion of the contract between the contracting authority and selected tenderer (Korpič-Horvat, 1997, p. 7). The National Audit Commission is an independent state authority for supervision of the legality of public procurement procedures (National Review Commission, 2010). The scrutiny carried out over public procurements by the Court of Audit is broader than that of the National Review Commission, which does not verify economy, purpose and efficient use of funds in public procurement awards (Public Procurement in Europe, 2005, p. 168).

From 2005 to 2008 public procurement procedures in the surveyed municipalities were subject to scrutiny in 68 cases. The most frequent supervisors were internal audit services (40\% of examinations), Court of Audit $(21 \%)$ and commercial auditors (19\%). In 18 municipalities, supervisors found no errors, while in 11 they only found administrative errors. In four municipalities poor 
internal controls were found, and in three cases municipalities were warned for having too many annexes to contracts.

In 2009 public procurement procedures in the surveyed municipalities were most frequently subject to scrutiny by internal audit services and commercial auditors, and only occasionally by the Court of Audit or National Review Commission. No public procurement infringements were found in most surveyed municipalities. In some, minor deficiencies were found such as disorganised documentation, strengthening internal controls, amendments to the tender dossier after deadlines expired.

\section{Conclusion}

Public procurements represent an important state instrument for stimulating the economy. The rules on public procurement inform contracting authorities of the conditions under which they can or must select goods suppliers or service providers for public sector requirements (Korelc, 2009, p.1).

The single European market also demands uniform legislation on public procurement. EU member states have started to incorporate European directives on public procurement into their own legislation. An international comparison of selected EU \& EEA member states indicates that the selected states have implemented Directives 2004/18/EC and 2004/17/EC in their public procurement legislation. The public procurement legislation of the selected states includes prescribed procedures for public tenders and public contract awards that must be respected in relation to threshold values for contracts. In all five selected states, contracting authorities can freely choose an open procedure, while in general legal regulations apply to the use of other procedures. The type and use of public procurement procedures are similar among the selected members, since they are all based on the EU directives, though each state has its own national peculiarities.

The research entitled "Awarding Work to External Contractors" studied the scope and method of issuing public contracts in Slovenian municipalities with over 8000 inhabitants. The study included 45 municipalities in 2008 and 25 in 2009. The scope and method of implementing public contracts differ from municipality to municipality. The most frequent services awarded to external contractors in the surveyed municipalities were cleaning services and 
Stanka Setnikar Cankar, Veronika Petkovšek

European public procurement directives and their implementation in Slovenia

vehicle fleet maintenance services, followed by security and information services, and less frequently legal services.

The tender and selection procedures a Slovenian municipality uses depend on the individual public procurement involved. Municipalities generally have internal acts defining the implementation of low-value public procurements. The majority of low-value public procurement awards are made with a purchase order, particularly for services. Services also dominate public procurements awarded by contract. Public procurements for goods are most frequently awarded by purchase order, and awarded by contract for construction.

High-value public procurements have legally prescribed procedures for public tenders. The most frequently used procedure among the surveyed municipalities over the years studied is an open procedure for goods and services and for construction. New public procurement legislation has introduced a number of new features, the dynamic purchasing system, electronic auction, and competitive dialogue to procedures for public tenders and awarding of public contracts, which make public procurement procedures more flexible and more effective.

In early 2007 the new act introduced the Ministry of Finance's public procurement portal, the purpose and great benefit of which is to reduce administrative obstacles and to modernise public procurement processes, offer onestop-shop access to information, reduce contracting authorities' costs and facilitate the shortening of deadlines. The creation of the portal also led to changes in how statistical data was reported to the Ministry of Finance. An automatic data reporting system for public procurement statistics started up in early 2009. Municipalities no longer had the obligation to report data on highvalue public procurements, since the data was automatically captured by the public procurement portal. Municipalities were exempt from the obligation to report statistical data on low-value procurements in 2008.

The external scrutiny of public procurement procedures is carried out by the Court of Audit and the National Review Commission. The scrutiny carried out over public procurements by the Court of Audit is broader than that of the National Review Commission, which does not verify economy, purpose and efficient use of funds in public procurement awards. In 2009 public procurement procedures in the surveyed municipalities were most frequently subject to scrutiny by internal audit services and commercial auditors, and rarely by the Court of Audit and National Review Commission. No public procurement infringements were found in most surveyed municipalities. 
Stanka Setnikar Cankar, Veronika Petkovšek

European public procurement directives and their implementation in Slovenia

Municipalities' responses to questionnaire completion were both positive and negative. Some municipalities have organised the field of public procurements very well and very systematically, but some are much poorer. It would therefore be of benefit to establish a standardised public procurement programme for municipalities, which would be regularly updated with data on public procurement type and value. Recordkeeping standards could also be defined to improve data collection, while offering interested parties access to the data. The authors would put forward Municipality of Laško as an example of best practice. The best practice of this and other municipalities should be transferred to municipalities that have not organised this sector to an acceptable level.

It is recommended that municipalities combine forces in the organisation and implementation of public procurements. The organisation of joint services for a group of municipalities would contribute to greater professionalism and effectiveness. A major contribution could be also made by standardising instructions on the selection of appropriate tenderers. Some people proposed the creation of independent, regional public procurement agencies that would ensure greater competition among potential providers, and bring together people with necessary skills and experiences.

Full Professor Stanka Setnikar-Cankar, Ph.D., graduated at the Faculty of Economics in Ljubljana in 1976. In 1993 she obtained the title of Doctor of Economics at the Faculty of Economics in Ljubljana. During the years 1999-2006 she carried out mandate as a Dean. She is a member of editorial boards of various professional journals in Slovenia and abroad. She is the managing editor of the journal "Uprava". She is a member of the NISPACee Steering Committee, a member of IIASIA, EGPA, etc. She successfully heads and participates in various research projects in field of Public Sector Reform, Effectiveness Measurement and Public Sector Economics. She participates in international research projects (Tempus, Interreg, Leonardo da Vinci). From 2009 she carries out her function again as the Dean of the Faculty of Administration and is a member of Strategic Council of the Republic of Slovenia for regionalisation.

Veronika Petkovšek graduated at the Faculty of Economics in Ljubljana in 2008. In 2008 she was employed at the Faculty of Administration as an assistant in the Department of Public Sector Economics. Her areas of research interest encompass Public Sector Economics in Slovenia in the field of changes in the healthcare system, public procurement and measuring the efficiency and effectiveness of public sector. She also participates at the international research projects, such as, Interreg and Leonardo da Vinci. 


\section{Stanka Setnikar Cankar, Veronika Petkovšek European public procurement directives and their implementation in Slovenia}

\section{References}

- Bohnec, I. et al. (2005). Vzorci aktov v postopkih javnih naročil in revizijskem postopku. Ljubljana: Nebra.

- $\quad$ National Review Commission. Retrieved 12.6.2010 from: http://www.dkom.si/?lng=slo\&vie=cnt\&gr1=pre\&gr2=pol.

- Evenett, S. J. \& Hoekman, B. M. (2005). International Cooperation and the Reform of Public Procurement Policies. CEPR Discussion Paper No. 4663.

- Federal Public Procurement Office. (2010). Vienna.

- Govekar, S. (2008). Javna naročila v Republiki Sloveniji s primerom javnega naročila za izvedbo gradnje. Ljubljana: B\&B, Višja strokovna šola.

- The International Comparative Legal Guide to: Public Procurement 2010. (2010). London: Global Legal Group Ltd.

- Korelc, Š. (2009). Problematika javnih naročil na ponudnikovi strani. Diplomsko delo. Ljubljana: Ekonomska fakulteta.

- Korpič - Hortvat, E. (1997). Revizijski postopek oddaje javnih naročil. Pravna praksa, št. 1.

- Kovač, M. (2010). Problem nepopolnih pogodb in mehanizmi pogodbenih spodbud pri javnih naročilih. Uprava, VIII (1-2), 187-211.

- Kranjc, V. (2004). Zakon o javnih naročilih z novelo ZJN-1A: Uvodna pojasnila dr. Vesna Kranjc. Ljubljana: GV Založba.

- Matas, S. (2006). Skupna javna naročila. Dnevi javnih naročil - 7. posvet. Portorož: Agencija za management.

- Mužina, A. \& Vesel, T. (2007). Zakon o javnem naročanju (ZJN-2) in Zakon o javnem naročanju na vodnem, energetskem, transportnem področju in področju poštnih storitev (ZJNVETPS) s pojasnili členov, pravom EU ter pravno prakso. Ljubljana: Nebra.

- Nemec, J. (2010). New Public Management and its Implementation in the CEE Region: What do we know and where do we go? Uprava, VIII (1-2), 7-36.

- Norway. Global Competition review. Retrieved 19.7.2010 from: http://Mww.globalcompetitionreview.com/handbooks/24/sections/87/chapters/911/norway/.

- Pivk, T. (2006). Problematika javnih naročil v javnem sektorju. Specialistično delo. Ljubljana: Ekonomska fakulteta.

- Public Procurement Portal. OGRS. Retrieved 17.7.2010 from: http://Mww.enarocanje.si/default.asp?podrocje=portal.

- Public procurement in Europe. (2005). Instituto poligrafico e Zecca dello Stato. Roma.

- Public Procurement. Swedish Competition Authority. Retrieved 19.7.2010 from: http://www.konkurrensverket.se/t/Page490.aspx. 
Stanka Setnikar Cankar, Veronika Petkovšek European public procurement directives and their implementation in Slovenia

- Setnikar-Cankar, S., Seljak, J., Petkovšek, V. (2009). Awarding work to external contractors in Slovenian municipalities. In: Pevcin, P. (ed.), Setnikar-Cankar, S. (ed.). Third International Symposium on the Development of Public Administration in South East Europe. Ljubljana, Slovenia. Ljubljana: Faculty of Administration.

- Šoltes, I. (2007). Prikaz pravne ureditve javnih naročil v Sloveniji in mednarodne primerjave skozi zgodovinski pregled. In: Ferfila B. (ed.): Ekonomski vidiki javnega sektorja. Ljubljana: Fakulteta za družbene vede.

- Public Procurement Act. OGRS, no 128/06, 16/08, 19/2010.

- The Act on Public Procurement in Water Management, Energy, Trasport and Postal Services. OGRS, no 128/06, 16/08. 
Stanka Setnikar Cankar, Veronika Petkovšek

European public procurement directives and their

implementation in Slovenia

POVZETEK

\section{EVROPSKE DIREKTIVE O JAVNIH NAROČILIH IN NJIHOVA IZVEDBA V SLOVENIJI}

Javna naročila so posebni postopki sklepanja pogodb za dobavo blaga, izvedbo storitev in gradenj. Javno naročanje mora spodbujati pošteno konkurenco med ponudniki in omogočiti naročniku, da nabavlja blago in storitve glede na zahtevano kakovost po najnižji ceni. Javna naročila morajo izvajati predvsem posredni in neposredni uporabniki državnega proračuna in lokalnih proračunov s ciljem najbolj gospodarno zadovoljiti svoje potrebe. Javna naročila pomenijo pomemben delež $v$ odhodkih iz državnega proračuna. Občine tako javnim naročilom namenjajo okoli $20 \%$ vseh odhodkov. $Z$ vzpostavitvijo konkurence zagotavljajo učinkovito alokacijo resursov ter uvajajo dinamiko konkurence $v$ relativno zaprte sisteme. Ustreznost javnega naročanja se kaže $v$ povečanju učinkovitosti in gospodarnosti porabe javnih financ, zanesljivosti in učinkovitosti delovanja javnega sektorja.

Javna naročila so pomemben instrument države pri spodbujanju gospodarstva. Pravila o javnem naročanju naročnikom zapovedujejo, pod katerimi pogoji morajo oziroma smejo izbirati dobavitelje blaga in izvajalce storitev za potrebe javnega sektorja. Postopek javnega naročanja se prične z opredelitvijo potrebe po nakupu naročnika. Naročnik pripravi razpisno dokumentacijo in določi predmet in obseg naročila, pogoje, ki jih morajo dosegati ponudniki, ter merila po katerih naročnik izbere najugodnejšega ponudnika. Sledi še sklenitev pogodbe in njeno izvajanje.

Države članice Evropske unije urejajo področje javnih naročil zaradi zasledovanja ciljev, kot so: učinkovitost porabe javnih sredstev, zagotavljanje odprte in popolne konkurence, zaupanje javnosti, racionalizacija poslovanja, preprečevanje korupcije, zagotavljanje enakopravnosti in nediskriminacije. Predvsem z vidika Evropske skupnosti pa so javna naročila tudi obsežna finančna sredstva in instrument zagotavljanja štirih svoboščin, na katerih temelji skupni trg.

Mednarodna primerjava izbranih članic EU kaže, da so izbrane članice v svoji zakonodaji na področju javnih naročil upoštevale Direktivo 2004/18/ES in Direktivo 2004/17/ES. V okviru zakonodaje o javnih naročilih imajo izbrane članice predpisane postopke razpisov in izbire javnih naročil, ki jih morajo upoštevati glede na predpisane mejne vrednosti naročil. V Avstriji lahko naročniki prosto izbirajo med odprtim postopkom 
in neodprtim postopkom po predhodni objavi. Na Madžarskem, Norveškem in Švedskem naročniki prosto izbirajo med odprtim postopkom in omejenim postopkom. Za uporabo drugih postopkov, kot so postopek s pogajanji, konkurenčni dialog, okvirni sporazum in dinamični sistem, pa veljajo zakonski predpisi v posameznih članicah.

Vrste in uporaba postopkov javnega naročanja med izbranimi članicami zelo podobni, saj vse v svoji zakonodaji upoštevajo Direktive ES. Vsaka izbrana članica pa ima tudi svoje nacionalne posebnosti. Tako na Madžarskem razlikujejo med postopki razpisov in izbire javnih naročil z eno fazo in postopke $z$ dvema fazama. $V$ Nemčiji lahko naročnik prosto izbira med predpisanimi postopki, če je bil predhodno objavljen vseevropski razpis. $V$ nasprotnem primeru mora uporabiti odprti postopek.

V okviru raziskave "Oddaja del zunanjim izvajalcem" smo proučili obseg in način izvajanja javnih naročil $v$ slovenskih občinah $z$ več kot 8.000 prebivalci $v$ letih 2008 in 2009. Pri raziskavi v letu 2008 je sodelovalo 45 občin, v letu 2009 pa 25 občin. Obseg in način izvajanja javnih naročil se med občinami razlikujeta. $V$ opazovanih občinah so $v$ obeh proučevanih letih najpogosteje oddajali zunanjim izvajalcem storitve čiščenja in storitve vzdrževanja voznega parka, sledile so storitve fizičnega varovanja in informacijske storitve, redkeje pa so oddajali pravne storitve.

Od posameznega javnega naročila je odvisno, kakšen postopek razpisa in izbire bo občina uporabila. Za naročila male vrednosti imajo občine izvajanje javnih naročil večinoma določeno po svojih internih aktih. Novi Zakon o javnem naročanju ne opredeljuje pojma oddaja naročil male vrednosti in zaradi poenostavitve ter večje fleksibilnosti za nabavo blaga in storitev do vrednosti 10.000 evrov in za gradnje $v$ vrednosti do 20.000 evrov ne predpisuje postopka naročanja. Za nabavo blaga in storitev $v$ vrednosti od 20.000 do 40.000 evrov in gradnje $v$ vrednosti od 40.000 do 80.000 evrov naročnik izvede postopek oddaje naročila male vrednosti ali katerikoli drug postopek. V letih 2008 in 2009 so največji delež oddaje malih naročil opravili z naročilnico, in sicer največ na področju storitev. Tudi na področju opravljanja javnih naročil s pogodbo so prevladovale storitve. Javna naročila za blago so najpogosteje sklepali z naročilnico, za gradnje pa s pogodbo.

Javna naročila velike vrednosti imajo zakonsko predpisane postopke zbiranja ponudb. Za javna naročila velike vrednosti, katerih vrednost je enaka ali večja od 40.000 evrov v primeru blaga in storitev oziroma 80.000 evrov $v$ primeru gradenj, je značilno, da naročnik izvede javno naročanje 
Stanka Setnikar Cankar, Veronika Petkovšek

European public procurement directives and their implementation in Slovenia

po enem izmed določenih postopkov: 1. odprti postopek, 2. postopek s predhodnim ugotavljanjem sposobnosti, 3. konkurenčni dialog, 4. postopek s pogajanji brez predhodne objave, 5 . postopek s pogajanji po predhodni objavi. Naročniki prosto izbirajo le med odprtim postopkom in postopkom s predhodnim ugotavljanjem sposobnosti, druge postopke pa izvedejo le, če so za to izpolnjeni posebni pogoji, ki jih določa zakon. Opazovane občine so v letih 2008 in 2009 najpogosteje uporabljale odprti postopek, tako pri zbiranju ponudb za blago in storitve kot tudi pri gradnjah. $V$ nekaterih občinah so redno ali pogosto uporabljali še postopke zbiranja ponudb po predhodni objavi, redkeje pa druge postopke.

Kot posledica dveh novih evropskih direktiv (Direktiva 2004/18/ES in Direktiva 2004/17/ES), katere sta sprejela Evropski parlament in Svet EU na koncu leta 2006, je nastala nova slovenska zakonodaja. Uporabljati se je pričela $v$ začetku leta 2007. Novi Zakon o javnem naročanju je prinesel številne novosti $v$ prakso javnega naročanja. Uvedel je nove postopke naročanja: dinamični sistem, elektronska dražba, konkurenčni dialog. To omogoča večjo fleksibilnost pri izvajanju javnega naročanja in uspešnejšo izvedbo javnih naročil. Vzporedno je bil sprejet tudi Zakon o javnem naročanju na vodnem, energetskem, transportnem področju in področju poštnih storitev.

Nova zakonodaja je $v$ začetku leta 2007 vpeljala portal javnih naročil Ministrstva za finance, katerega namen in prednost so predvsem zmanjšanje administrativnih ovir in posodobitev načina poslovanja pri javnem naročanju, dostopnost informacij na enem mestu, zmanjšanje stroškov za naročnike in možnost skrajšanja rokov. Z vzpostavitvijo portala je prišlo je tudi do spremembe sporočanja statističnih podatkov na Ministrstvo za finance. Vzpostavljen je bil sistem za sprotni zajem statističnih podatkov o javnih naročilih, ki je začel veljati $v$ začetku leta 2009. Za leto 2009 ni bilo več treba sporočati podatkov o javnih naročilih velike vrednosti, saj se zajemajo neposredno iz portala javnih naročil. Pri obveznosti sporočanja statističnih podatkov za mala naročila pa so bile občine izvzete že za leto 2008.

Zunanji nadzor nad postopki javnega naročanja izvajata Računsko sodišče in Državna revizijska komisija. Nadzor, ki ga pri javnih naročilih opravlja Računsko sodišče, je širši od revizije Državne revizijske komisije, saj le-ta ne ugotavlja gospodarnosti, namembnosti in učinkovitosti rabe sredstev za oddano javno naročilo. $V$ opazovanih občinah so bila javna naročila najpogosteje predmet nadzora notranje revizijske službe in 
komercialnih revizijskih hiš, ponekod pa tudi Računskega sodišča in Državne revizijske komisije. Pri večini opazovanih občinah kršitev pri javnih naročilih ni bilo ugotovljenih.

Pri izpolnjevanju vprašalnikov smo naleteli na dobre in slabe odzive občin. Nekatere občine imajo področje javnih naročil zelo dobro in sistematično urejeno, nekatere slabše. Zato bi bilo dobro, da se vzpostavi enoten program javnih naročil po občinah, kjer bi sprotno vnašali podatke po vrstah javnih naročil in vrednostih. Podobno bi lahko vzpostavili enotne standarde vodenja evidenc za lažje zbiranje podatkov in hkrati posledično tudi omogočili zainteresirani javnosti dostop do podatkov. Primer dobre prakse pri javnih naročilih je občina Laško. Njeno prakso in tudi dobre prakse drugih občin bi bilo treba prenesti na občine, kjer tega področja še nimajo dovolj dobro urejenega. 